\title{
EXPLORING STUDENTS' SPEAKING ABILITY AT MUHAMMADIYAH SORONG UNIVERSITY (UMS)
}

\author{
Kris Uluelang \\ Department of English Education, Faculty of Teacher Training and Education, \\ University of Muhammadiyah Sorong \\ Email: krisuluelang.ums@gmail.com
}

\begin{abstract}
This research tried to find out how is students' speaking ability at University Muhammadiyah Sorong. This research used qualitative method and descriptive design. The population is students of English department at University of Muhammadiyah Sorong in 2013/2014 academic year. The writer took only 30 students randomly of fifth semester as the sample of this research. The writer also prepared some topics that chosen by the students and used voice recorder as the research instruments to measure students' speaking ability. The result of this research revealed that the students' speaking ability at University of Muhammadiyah Sorong was poor. The detail aspect of speaking occurred, Pronunciation was good, Grammar was fair, Vocabulary was fair, Fluency was poor, and Comprehension was poor which based on 30 respondents of fifth semester of English Education Department at University of Muhammadiyah Sorong.
\end{abstract}

Keywords: language, speaking, speaking ability

\section{INTRODUCTION}

As we know together, English is an international language. When people meet each other's from different countries, they should use English as their united language. In many countries, English become a second language in communication but in Indonesia, it is a foreign language after vernacular and Bahasa Indonesia. Evans and Maggie (1998:53) stated that English has become the international language of business. In Indonesia, mastery of English is one of plus point to be received as an employee of an enterprise. Many enterprises ask for English certificate as the requirement of the job. They want the employee can communicate with English orally and written.

To be an English teacher, we should to mastery English speaking well. Nowadays, along with the strengthening position of English as a language for international communication, the teaching of speaking skill has become increasingly important in the English as a second or foreign language (ESL/EFL) context. (Widiati and Bambang, 2006: 269). There are three main reasons for getting students to speak in the classroom. Firstly, speaking activities provide rehearsal opportunities chance to practice real-life speaking in the safety of the classroom. Secondly, speaking task in which students try to use any or all of the language they know provide feedback for both teacher and students. And finally, the more students have opportunities to activate the various elements of language they have stored in their brains, the more automatic their use of these elements become. (Harmer, 2007:123)

Speaking becomes the first goal in learning language. The main aim of English 
education department student is to be teacher. For the university students, it will be proved when they start to teach as teachers in practice to speak in front of the class. Listeners will become the judges to them, when they can speak well they will recognize their ability and the other way. Inspired by the phenomena mentioned above, the writer will further explore about speaking of student at University of Sorong Muhammadiyah. The problem of the research is: how is students' speaking ability at University of Muhammadiyah Sorong?

\section{METHOD}

The research method applied qualitative descriptive analysis approach to analyze all data has been collected. Using random sampling technique, the subject of this study will be applied for 30 students of English Department which is selected on fifth semester at Muhammadiyah Sorong University.

\section{Research Instruments}

The writer used some topics and voice recorder as the research instruments to measure students' speaking ability.

\section{Data Analysis}

In this research, the descriptive statistical method is used to analyze the data about exploring students' speaking ability at Muhammadiyah Sorong University Sorong in 2013/2014 academic year.

$$
\begin{aligned}
& -X=\begin{array}{c}
\Sigma x \\
n
\end{array} \\
& X \quad=\text { mean score of the groups } \\
& \Sigma x \quad=\text { the total of all students' score } \\
& n \quad=\text { the number of students }
\end{aligned}
$$

(Sudjana, 1989)

After analyzing the scores obtain by using the formula above, the result is consult to the following classification level of the test.

\begin{tabular}{cc}
\hline Percentage $(\boldsymbol{\%})$ & Category \\
\hline $85-100$ & Very good \\
$70-84$ & Good \\
$55-69$ & Fair \\
$40-54$ & Poor \\
$0-39$ & Very poor \\
\hline
\end{tabular}

(Asmani, 2011:190)

\section{FINDING}

In this section, the writer classified the result of speaking test of the students. There are 30 students that followed this test. After analyzing the data, the writer got students' speaking score as follows: 


\section{Graphic 1}

Percentage of Students' Speaking Test

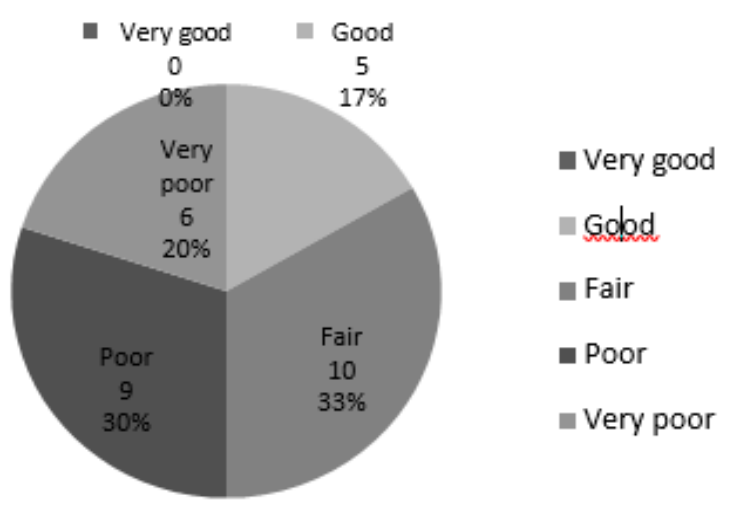

In addition, based on Graphic 1, the writer can summarize the number of students' speaking test on percentage which, no one student was on very good category or $0 \%, 5$ students were on good category or 17\%, 10 students were on fair category or 33\%, 9 students were on poor category or $30 \%$, and 6 students were on very poor category or $20 \%$. So, the average of students' speaking test was $54 \%$ or on poor category.

The graphics below show the score from each item of speaking such as pronunciation, grammar, vocabulary, fluency and comprehension.

Graphic 2

Percentage of Students' Pronunciation

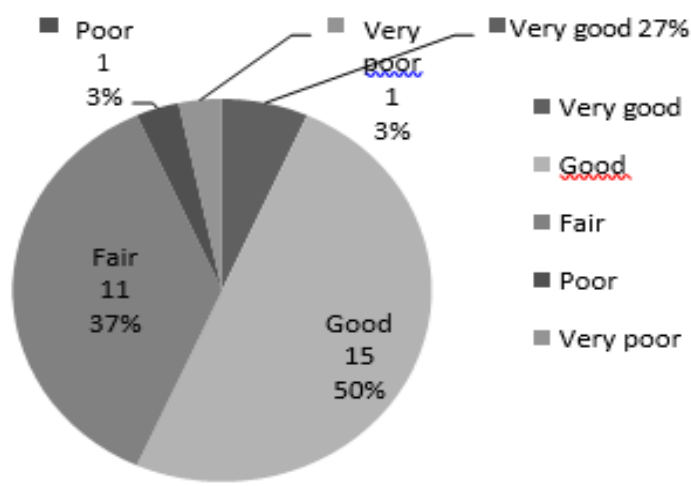

Based on Graphic 2, the writer can summarize the number of students' pronunciation on percentage which, 2 students were on very good category or $7 \%, 15$ students were on good category or $50 \%, 11$ students were on fair category or $37 \%, 1$ student was on poor category or $3 \%$, and 1 student was on very poor category or $3 \%$. So, the average of students' pronunciation was $71 \%$ or on good category. 


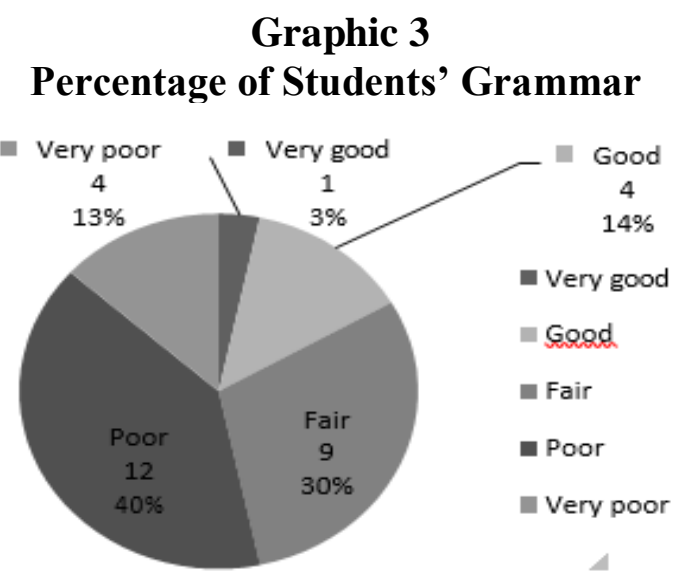

Based on Graphic 3, the writer can summarize the number of students' grammar on percentage which, 1 student was on very good category or 3\%, 4 students were on good category or $14 \%, 9$ students were on fair category or $30 \%, 12$ students were on poor category or $40 \%$, and 4 students was on very poor category or $13 \%$. So, the average of students' grammar was $51 \%$ or on fair category.

\section{Graphic 4}

Percentage of Students' Vocabulary

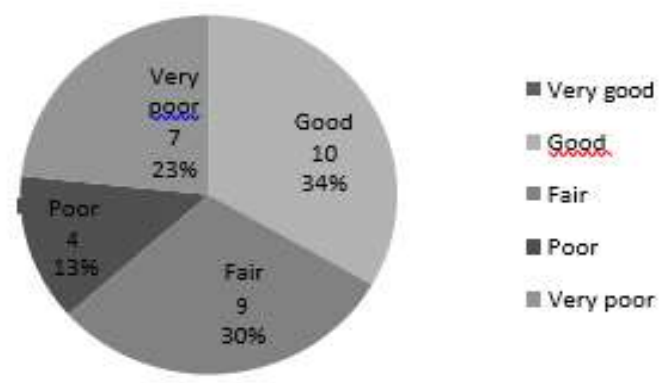

Based on Graphic 4, the writer can summarize the number of students' vocabulary on percentage which, no one students was on very good category, 10 students were on good category or $34 \%, 9$ students were on fair category or $30 \%, 4$ students was on poor category or $13 \%$, and 7 student were on very poor category or $7 \%$. So, the average of students' pronunciation was $55 \%$ or on fair category.

\section{Graphic 5}

\section{Percentage of Students' Fluency}

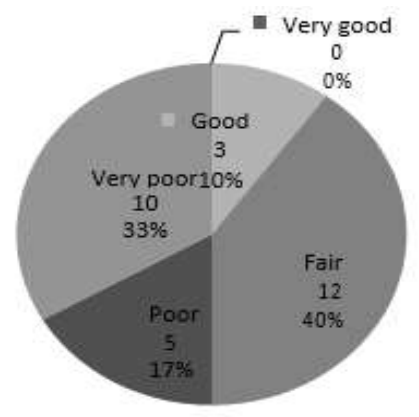

$$
\begin{aligned}
& \text { wery good } \\
& \text { = Good } \\
& \text { = Fair } \\
& \text { = Poor } \\
& \text { = Very poor }
\end{aligned}
$$


Based on Graphic 5, the writer can summarize the number of students' fluency on percentage which, no one students was on very good category, 3 students were on good category or $10 \%, 12$ students were on fair category or $40 \%, 5$ students were on poor category or $17 \%$, and 10 students were on very poor category or $33 \%$. So, the average of students' fluency was $45 \%$ or on poor category.

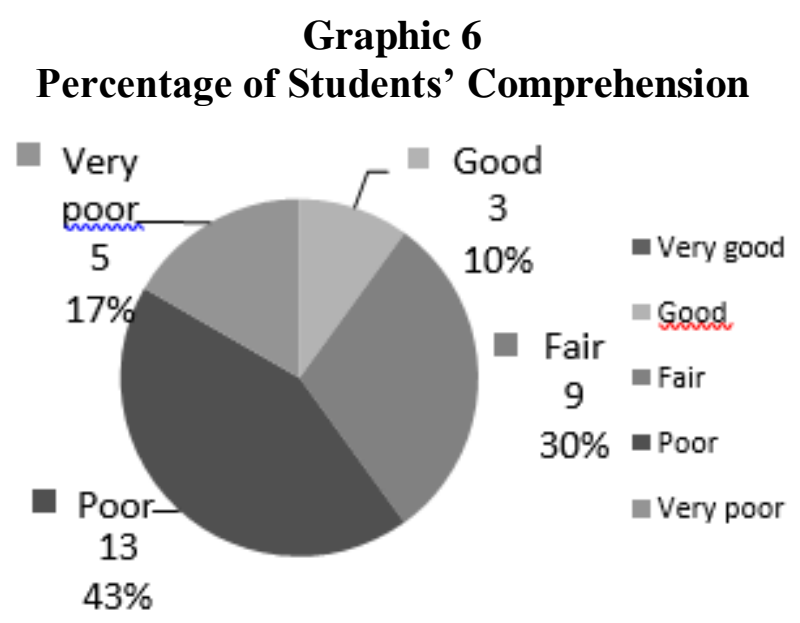

Based on Graphic 6, the writer can summarize the number of students' comprehension on percentage which, no one students was on very good category, 3 students were on good category or 10\%, 9 students were on fair category or 30\%, 13 student were on poor category or $43 \%$, and 5 students were on very poor category or $17 \%$. So, the average of students' pronunciation was $47 \%$ or on poor category.

\section{DISCUSSION}

In this section, the writer will describe the data found. It is also the result of analysis of students' speaking ability. The tables below shows the students' score of five aspects on speaking from 10 students.

Table 1

Analysis of Student's speaking

\begin{tabular}{|c|c|}
\hline \multicolumn{2}{|l|}{$\begin{array}{l}\text { Respondent 1: AN } \\
\text { Pronunciation }\end{array}$} \\
\hline $\begin{array}{l}\text { Incorrect: Charge: /char/ } \\
\text { Because: / bi'kaws/ Student: /stadent/ Finished: } \\
\text { /'finishid/ Only: /'anli/ Purpose: /'purpows/ } \\
\text { Eventhough: } \\
\text { /'ievəndough/ }\end{array}$ & $\begin{array}{l}\text { Correct: Charge: /carj/ } \\
\text { Because: / bi'kaws/ Student: /'stuwdənt/ } \\
\text { Finished: /'finisyd/ Only: /'ownlie/ } \\
\text { Purpose: /'pərpəs/ Eventhough: } \\
\text { /'ievənthow/ }\end{array}$ \\
\hline Grammar & \\
\hline $\begin{array}{l}\text { Error: } \\
\text { - Why that many student... } \\
\text { - If government free of charge } \\
\text { education in Indonesian... } \\
\text { - Many student can't finished her or his school.... } \\
\text { - Many student cannot school } \\
\text { - } \\
\text { Government have the purpose administer } \\
\text { free of charge especially of education. } \\
\text { Many people, } \\
\text { many student } \\
\text { especially can't school. }\end{array}$ & $\begin{array}{l}\text { Correct: } \\
\text { - Why there are any students... } \\
\text { - } \quad \text { If the government gives free of charge } \\
\text { education in Indonesia.... } \\
\text { - Many students can't finish her or his } \\
\text { school.... } \\
\text { Many students cannot school } \\
\text { - Government has a purpose to } \\
\text { administer free of charge especially for } \\
\text { education. } \\
\text { Many people, especially many }\end{array}$ \\
\hline
\end{tabular}




\begin{tabular}{l|l}
\hline $\begin{array}{l}\text { I think can make student aa.. easy for ee finished his } \\
\text { or her education }\end{array}$ & $\begin{array}{l}\text { students can't school. } \\
\text { I think it can make students easy to } \\
\text { finish his or her education }\end{array}$ \\
\hline Vocabulary & $\begin{array}{l}\text { Correct: } \\
\text { in Indonesia. }\end{array}$ \\
\hline Inappropriate: in Indonesian & \\
\hline Fluency & \\
\hline Speech is as halting and fragmentary as to make conversation virtually impossible.
\end{tabular}

\section{Comprehension \\ Has great difficulty, follow what is said. Can comprehend only "social comprehension" so can slowly and with frequent repetitions.}

\begin{tabular}{l|l}
\hline \multicolumn{2}{l}{ Respondent 2: ARS } \\
\hline Pronunciation & Correct: \\
\hline Incorrect: & Building: /bilding/ Through: /thruw/ \\
Building: /building/ Through: /trogh/ Knowledge: & Knowledge: /'nalij/ All: /ol/ \\
/knowlidj/ All: /al/ & Because: /bi'kos/ Detail: /di'teil/ \\
Because: / bi'kaws/ Detail: /ditail/ Know: /naw/ & Know: /now/ \\
\hline
\end{tabular}

\begin{tabular}{|c|c|}
\hline Grammar & \\
\hline $\begin{array}{l}\text { Error: } \\
\text { - 'Pesantren Kilat' building the student about other } \\
\text { knowledge especially for the religy. } \\
\text { - 'Pesantren Kilat' about the topic about for all for } \\
\text { all materi for for Muslim and.....building for the } \\
\text { student very very important for student. }\end{array}$ & $\begin{array}{l}\text { Correct: } \\
\text { - 'Pesantren Kilat' builds the students' } \\
\text { knowledge especiallyabout religion. } \\
\text { - 'Pesantren Kilat' teach us all about } \\
\text { Islam and it's very important for } \\
\text { student. }\end{array}$ \\
\hline
\end{tabular}

- 'Pesantren Kilat' building the student remember remember and review the study about religy religy subject.

- the student must study about the religy subject.

- .. in "Pesantren Kilat" ee building character for the.... Student

- ...the student ee more more detail study about ee Musli ee religi subject...

- what what what ee what video what video ehm what video the ee nabi and ee read to read to al-qur'an of the name 'mengaji' and more more detail ee more detail study about ee religi subject.

- 'Pesantren Kilat', ee very very important building character for the student and and the and the student and the student ee have have ee more detail religi subject..

- after follow the 'Pesantren Kilat'

- in "Pesantren Kilat" the student the student the student ee the st the the in "Pesantren Kilat" the student ee activity, their activity same the in home at home ee especially ee pray for ashar, pray for dzuhur and etc.

- ... in "Pesantren Kilat" character building of the student more detail more detail again in pray and mengaji and etc.

- ... and then and "Pesantren Kilat" ee the student must the student must more ee more have

- 'Pesantren Kilat' reminds the student to study about religion.

- The student must study about religion.

- 'Pesantren Kilat' builds the students' character.

- ...the student can study more about religion.

- Watching video about prophet and reading Al-Qur'an which called as 'mengaji' and study more about religion.

- 'Pesantren Kilat' is very important for building the character of student and student can study more about religion.

- after following 'Pesantren

Kilat'

- in 'Pesantren Kilat', the students' 


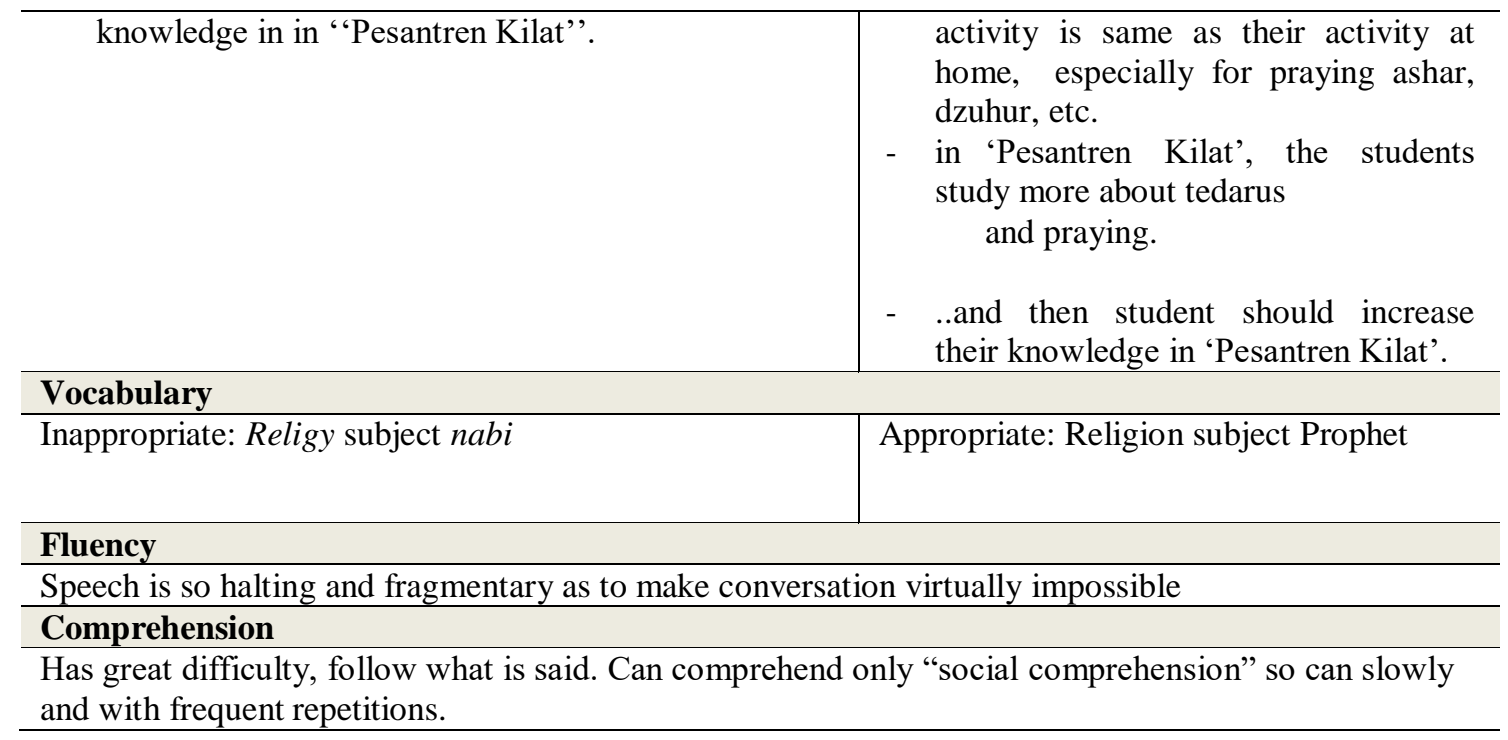

\begin{tabular}{|c|c|}
\hline \multicolumn{2}{|l|}{ Respondent 3: AS } \\
\hline $\begin{array}{l}\text { Incorrect: Charge: /chens/ } \\
\text { Education: /'edukesen/ Important: /importat/ Always: } \\
\text { /'owelz/ } \\
\text { Our: /owr }\end{array}$ & $\begin{array}{l}\text { Correct: Charge: /carj/ } \\
\text { Education: } \\
\text { /'eju'keisyən/ Important: /im'portənt/ } \\
\text { Always: /'olweiz/ } \\
\text { Our: /awr/ }\end{array}$ \\
\hline & \\
\hline $\begin{array}{l}\text { Error: } \\
\text { - ...because you give me time for I. } \\
\text { I just talking } \\
\text {-..free charge in Indonesia is very total for us. } \\
\text { Sometimes, I watching television talk about the } \\
\text { education so about education so. } \\
\text { I think I think education education total for us in } \\
\text { Indonesia but eee Papua I think I think ee education } \\
\text { in Indonesia same same for the conflict } \\
\text { but ee Papua just enough. } \\
\text { I why why I say for eeee education of Papua enough } \\
\text { because maybe maybe eee teacher teacher and then } \\
\text { and then ee facilities fasilitas in ee education Papua. } \\
\text { I think I think the education education education ee } \\
\text { important for us and then must must must it think ee } \\
\text { if you want if you want if you want ee must think } \\
\text { about the education and then eee if if next time next } \\
\text { time for education. } \\
\text { and then we must say people if you... or if you want } \\
\text { much education... } \\
\text { and then maybe maybe teacher teacher teacher give } \\
\text { they are motivasi-motivasi about education... } \\
\text {...people ask ask ask government so that government } \\
\text { give us give us free eee education education. } \\
\text { I think I think if you want maybe maybe if it's } \\
\text { enough I think enough } \\
\text { - pendi education... }\end{array}$ & $\begin{array}{l}\text { Correct: } \\
\text { - ..because you give me time. } \\
\text { I'm just talking } \\
\text {... free of charge education in } \\
\text { Indonesia is totally for us. } \\
\text { Sometimes, I watch televisionthat } \\
\text { talking about education also. } \\
\text { - I think education is totally for all of us } \\
\text { in Indonesia but in Papua, the } \\
\text { education is not same. The education } \\
\text { in Papua is not enough. } \\
\text { - Why did I say that? Because maybe } \\
\text { the teacher and the facilities to support } \\
\text { the education in Papua are not enough. } \\
\text { I think education is important for us } \\
\text { and we must think about what we want } \\
\text { in education for next time. }\end{array}$ \\
\hline
\end{tabular}


... so that so that maybe maybe so ee check ee I think I think ee student check ee program language English if about ee education.

- maybe maybe ee program other I don't know but but ee education ...people asked to the government, so that the government give us the free of charge education for us.

I think, maybe the education is enough.

...so, I think maybe student can check

English education program.

...maybe another education program...

Appropriate:

Motivations

\section{Vocabulary}

Inappropriate:

Motivasi-motivasi

Fluency

Speed and fluency are rather strongly affective by language problems.

\section{Comprehension}

Has great difficulty, follow what is said. Can comprehend only "social comprehension" so can slowly and with frequent repetitions.

\begin{tabular}{|c|c|}
\hline \multicolumn{2}{|l|}{ Respondent 4: AP } \\
\hline \multicolumn{2}{|l|}{ Pronunciation } \\
\hline $\begin{array}{l}\text { Incorrect: } \\
\text { Charge: /char/ Large: /lars/ }\end{array}$ & $\begin{array}{l}\text { Correct: } \\
\text { Charge: /carj/ Large: /larj/ }\end{array}$ \\
\hline \multicolumn{2}{|l|}{ Grammar } \\
\hline $\begin{array}{l}\text { Error: } \\
\text { - I agree in gov of government about the program.... } \\
\text { - ..education is ameans.. } \\
\text { - I hope of } \\
\text { government in Indonesia about a program of free } \\
\text { education to to until in until theority. } \\
\text { Because to to less of displation. }\end{array}$ & $\begin{array}{l}\text { Correct: } \\
\text { - I agree about government } \\
\text { program... } \\
\text { - ..education means.. } \\
-\quad \text { I hope the } \\
\text { government of Indonesia can give free } \\
\text { education until in university. } \\
\text { Because it can decrease } \\
\text { distinction. }\end{array}$ \\
\hline \multicolumn{2}{|l|}{ Vocabulary } \\
\hline $\begin{array}{l}\text { Inappropriate: } \\
\text { Displation Theority }\end{array}$ & $\begin{array}{l}\text { Appropriate: } \\
\text { Distinction University }\end{array}$ \\
\hline \multicolumn{2}{|l|}{ Fluency } \\
\hline \multicolumn{2}{|c|}{ Speech is so halting and fragmentary as to make conversation virtually impossible } \\
\hline \multicolumn{2}{|c|}{ Comprehension } \\
\hline
\end{tabular}

\section{Respondent 5: ATS}

\section{Pronunciation}

Incorrect: Charge: /cars/ Facts: /fest/

Environment: /en'veronment/ Importantly: /

im'portantli/
Correct: Charge: /carj/ Facts: /fækts/

Environment:

/en'vairənmənt/ Importantly:

/im'portəntli/

\begin{tabular}{l|l}
\hline Grammar & \multicolumn{2}{l}{ Correct: } \\
\hline Error: & $-\quad$ From three topics, \\
- $\quad$ From three topic, & $-\quad$ It doesn't have to do... \\
- It don't have to do... & $-\quad$ It makes free of charge education in \\
\hline
\end{tabular}




\begin{tabular}{|c|c|}
\hline $\begin{array}{ll} & \text { is facts it facts. } \\
\text { - } & \text { Most of most of teacher must be teach well. } \\
\text { - } & \text { They also need a have, } \\
\text { - } & \text { They have a need to take care... } \\
\text { - } & \text { Take care their family or anyone... } \\
\text { - } & \text { It makes the many people.... } \\
\text { - } & \text { There many matters } \\
\text { - } & \text { Environment don't have to do such as } \\
\text { - } & \text { corruption or just it. } \\
\text { - } & \text { That's all my opinion about about it about that. }\end{array}$ & $\begin{array}{ll} & \text { Indonesia is real. } \\
\text { - } & \text { Most of teachers must teach well } \\
\text { - } & \text { They also have a need, } \\
\text { - } & \text { They have to take care... } \\
\text { - } & \text { Take care to their family or everyone... } \\
\text { - } & \text { There are many matters } \\
\text { - } \quad \text { Government doesn't have to do } \\
\quad \text { corruption or another. } \\
\text { - That's all my opinion about that. }\end{array}$ \\
\hline \multicolumn{2}{|l|}{ Vocabulary } \\
\hline $\begin{array}{l}\text { Inappropriate: Environment don't have to do such as } \\
\text { corruption or just it. Cannot applicate Many matters }\end{array}$ & $\begin{array}{l}\text { Appropriate: Government doesn't have to do } \\
\text { corruption or another. Cannot be applied } \\
\text { Many problems }\end{array}$ \\
\hline \multicolumn{2}{|l|}{ Fluency } \\
\hline \multicolumn{2}{|c|}{ Speed and fluency are rather strongly affective by language problems. } \\
\hline Comprehension & \\
\hline
\end{tabular}

\begin{tabular}{|c|c|}
\hline \multicolumn{2}{|l|}{ Respondent 6: AIS } \\
\hline \multicolumn{2}{|l|}{ Pronunciation } \\
\hline $\begin{array}{l}\text { Incorrect: } \\
\text { Because: / bi'kaws/ Heard: /hard/ World: /werd/ } \\
\text { Develop: /develop/ } \\
\text { Relation: /relesyən/ Fair: /feir/ }\end{array}$ & $\begin{array}{l}\text { Correct: Because: /bi'kəs/ Heard: / hərd/ } \\
\text { World: /wərld/ } \\
\text { Develop: /di'veləp/ Relation: /ri'leisyən/ } \\
\text { Fair: /fær/ }\end{array}$ \\
\hline \multicolumn{2}{|l|}{ Grammar } \\
\hline 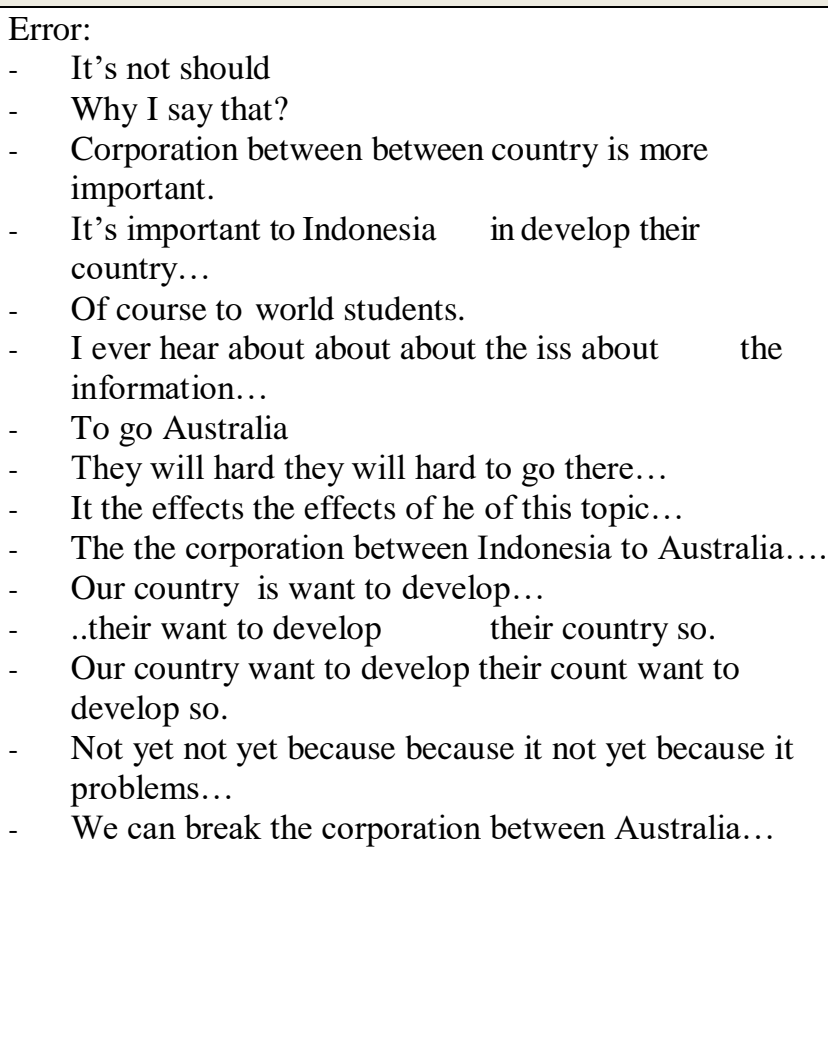 & $\begin{array}{l}\text { Correct: } \\
\text { - } \quad \text { It should not } \\
\text { - } \quad \text { Why did I say that? } \\
\text { - Corporation between both countries is } \\
\text { more important. } \\
\text { - It's important to Indonesia in } \\
\text { developing their country.... } \\
\text { - } \quad \text { Of course to foreign students. } \\
\text { - } \quad \text { I ever heard about the information. } \\
\text { - } \quad \text {..to go to Australia } \\
\text { - } \quad \text { It will be hard to go there. } \\
\text { - It is the effect of this topic. } \\
\text { - The corporation between Indonesia and } \\
\text { Australia. } \\
\text { Our country wants to develop... } \\
\text { - } \quad \begin{array}{l}\text {...they want their country develop to. } \\
\text { Our country wants to develop, theirs do }\end{array} \\
\text { to. } \\
\text { Not because the problems, } \\
\text { - We can break the corporation to } \\
\text { Australia... }\end{array}$ \\
\hline
\end{tabular}




\begin{tabular}{l|l}
\hline Vocabulary & \\
\hline $\begin{array}{l}\text { Inappropriate: World the students } \\
\text { Mengatasi }\end{array}$ & $\begin{array}{l}\text { Inappropriate: World the students } \\
\text { Mengatasi }\end{array}$ \\
\hline Fluency & \\
\hline Speech as speech seems to be slightly affected by language problems. \\
\hline Comprehension \\
\hline Understand nearly everything at normal speed, although occasional repetition may be necessary \\
\hline
\end{tabular}

\section{Respondent 7: DPA}

Pronunciation

Incorrect: Building: /bulding/ Through: /thrugh/ Your: /yor/

\section{Correct:}

Building: /bilding/ Through: /thruw/

Your: /yur/

\begin{tabular}{|c|c|}
\hline \multicolumn{2}{|l|}{ Grammar } \\
\hline $\begin{array}{l}\text { Error: } \\
\text { - } \quad \text { I choose ee the topic is character building through } \\
\text { 'Pesantren Kilat'. } \\
\text { - ... it be held of Ramadhan. } \\
\text { - } \quad \text { In this ee in this of 'Pesantren Kilat'... } \\
\text { - ...we have wake up ee wake up at } 5 \text { o'clock, } \\
\text { - } \quad \text {..after wake up we have praying, } \\
\text { - ...after praying we have ee clean your bad, } \\
\text { - ...clean your bad after bad, } \\
\text { - ... after take a shower... } \\
\text { - ... you and your friend ee reading the al-qur'an, } \\
\text {... the the teacher of ee in 'Pesantren Kilat' make ee } \\
\text { has ee give give the material..... } \\
\text {... in after after that after that the material... } \\
\text {...next ee the material about next the material about ee } \\
\text { next the material... } \\
\text {...after next the material ee after that you praying } \\
\text { ashar.. } \\
\text { Maybe this ee you character building is maybe you is } \\
\text { very well, you is ... } \\
\text {... after that ee you praying magrib and take ee maybe } \\
\text { you eat ee you eat with your friend. } \\
\text {...you're reading aa the al-qur'an with your friend, } \\
\text { your your full your heart. } \\
\text { Maybe ee, okay just enough. }\end{array}$ & $\begin{array}{l}\text { Correct: } \\
\text { - I choose this topic, character building } \\
\text { through 'Pesantren Kilat'. } \\
\text { - ... hit holds in Ramadhan. } \\
\text { - In 'Pesantren Kilat', } \\
\text { - ...we have to wake up at } 5 \text { o'clock, } \\
\text { - ...after waking up, we have to pray, } \\
\text { - ...after praying, we have to clean our } \\
\text { bad, } \\
\text {-..clean your bad after sleeping, } \\
\text { - ...after taking shower... } \\
\text { - ...you and your friend read the Al- } \\
\text { Qur'an, } \\
\text {...In 'Pesantren Kilat', the teacher will } \\
\text { give a speech. } \\
\text { After the speech... } \\
\text { About the next speech. } \\
\text { - } \\
\text { After the next speech, you have to pray } \\
\text { ashar... } \\
\text { Maybe the character building can } \\
\text { make you to be good, you are.... } \\
\text {...after that you have to pray magrib and } \\
\text { then eat with your friends. } \\
\text {...you and your friends read Al- Qur'an } \\
\text { with pleasure. } \\
\text { Okay, it is enough. }\end{array}$ \\
\hline \multicolumn{2}{|l|}{\begin{tabular}{|l|l|} 
Vocabulary & \\
\end{tabular}} \\
\hline \multicolumn{2}{|c|}{ limitations so extreme as to make conversation virtually impossible } \\
\hline \multicolumn{2}{|l|}{ Fluency } \\
\hline \multicolumn{2}{|c|}{ Speed and fluency are rather strongly affective by language problems } \\
\hline \multicolumn{2}{|l|}{ Comprehension } \\
\hline $\begin{array}{l}\text { Has great difficult } \\
\text { comprehension" }\end{array}$ & cial \\
\hline
\end{tabular}




\begin{tabular}{l} 
Respondent 8: EJ \\
Pronunciation \\
\hline Incorrect: \\
Break: /brek/ \\
Problem: /'problom/ \\
Handphone: / \\
hændpown/ \\
Government: / \\
Example: /ig'zampol/ \\
Grammar
\end{tabular}

Correct:

Break: /breik/

Problem: /'prabləm/

Handphone: /hændfown/

Government:

/'g $\Lambda$ vərnmont/

Example: /eg'zæmpəl/

Correct:

- There is a problem between Indonesia and Australia.

I think the problem is tapping.

When Australia tapped the mobile phone of president of Indonesia...

Indonesia respond Australia by sending a letter to the government of Australia...

- ...the government of Australia didn't respond the letter from the government of Indonesia...

...the government of Australia said that they didn't do the tapping...

...they didn't ask apologize to the government of Indonesia.

...the relationship between people of Indonesia that live in Australia and the people of Australia is good because the problem that occurs is just between the relationships of both countries.

I think the government of Australia should ask apologize to the government of Indonesia...

The government of Indonesia is trying to make a good relationship to another country...

...the government in Indonesia should be focus should be focus on the problem of corruption...

Forexample, analyzing, completing and finding the solution of the corruption problem...

Thanks for the opportunity that given to me to talk about... 


\begin{tabular}{l|l}
\hline people Indonesian people Another people & $\begin{array}{l}\text { The problem is tapping People of Australia } \\
\text { People of Indonesia Other peoples }\end{array}$ \\
\hline Fluency & \\
\hline Speech as speech seems to be slightly affected by language problems. \\
\hline Comprehension & \\
\hline \multicolumn{2}{l}{ Understand nearly everything at normal speed, although occasional repetition may be necessary } \\
\hline
\end{tabular}

\begin{tabular}{|c|c|}
\hline \multicolumn{2}{|l|}{ Respondent 9: FA } \\
\hline \multicolumn{2}{|l|}{ Pronunciation } \\
\hline $\begin{array}{l}\text { Incorrect: } \\
\text { Building: /building/ Student: /stadən/ Month: } \\
\text { /moun/ Knowledge: /knowledj/ Because; /'bikaws/ } \\
\text { Pornography: } \\
\text { /'pornografi/ College: /colleg/ Learning: } \\
\text { /lirning/ }\end{array}$ & $\begin{array}{l}\text { Correct: } \\
\text { Building: /bilding/ Student: /'stuwdənt/ Month: } \\
\text { /m^nth/ Knowledge: /'nalij/ Because; / bi'kəs/ } \\
\text { Pornography: } \\
\text { /po'nagrəfie/ College: /'kalij/ Learning: } \\
\text { /lərning/ }\end{array}$ \\
\hline \multicolumn{2}{|l|}{ Grammar } \\
\hline $\begin{array}{l}\text { Error: } \\
\text { - } \quad \text { 'Pesantren Kilat' usually doing... } \\
\text { - } \quad \text { 'Pesantren Kilat' give many knowledge } \\
\text { about islam religion. } \\
\text { - } P \text { Pesantren Kilat' usually learn learning } \\
\text { learning... } \\
\text { - 'Pesantren Kilat' learning they } \\
\text { - 'Pesantren Kilat' give benefit... } \\
\text { - } \quad \text { 'Pesantren Kilat' learning they help people }\end{array}$ & $\begin{array}{l}\text { Correct: } \\
\text { - 'Pesantren Kilat' usually do.... } \\
\text { - } \quad \text { 'Pesantren Kilat' gives many knowledge } \\
\text { about Islam. } \\
\text { - 'Pesantren Kilat' usually learn.. } \\
\text { - 'Pesantren Kilat' teaches them. } \\
\text { - 'Pesantren Kilat' gives benefit... } \\
\text { - 'Pesantren Kilat' teach them to help other } \\
\text { people. }\end{array}$ \\
\hline \multicolumn{2}{|l|}{ Vocabulary } \\
\hline 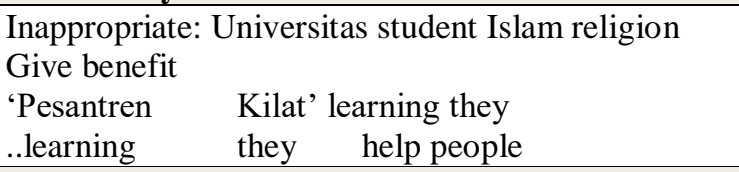 & $\begin{array}{l}\text { Appropriate: University student Islam } \\
\text { Give advantage 'Pesantren Kilat' teach them } \\
\text {...teach them to help people }\end{array}$ \\
\hline \multicolumn{2}{|l|}{ Fluency } \\
\hline \multicolumn{2}{|l|}{$\begin{array}{l}\text { Usually hesitant often forced into silence by } \\
\text { language limitations }\end{array}$} \\
\hline \multicolumn{2}{|l|}{ Comprehension } \\
\hline $\begin{array}{l}\text { Understand most of what is said at slower than } \\
\text { normal speed with repetitions. }\end{array}$ & \\
\hline
\end{tabular}




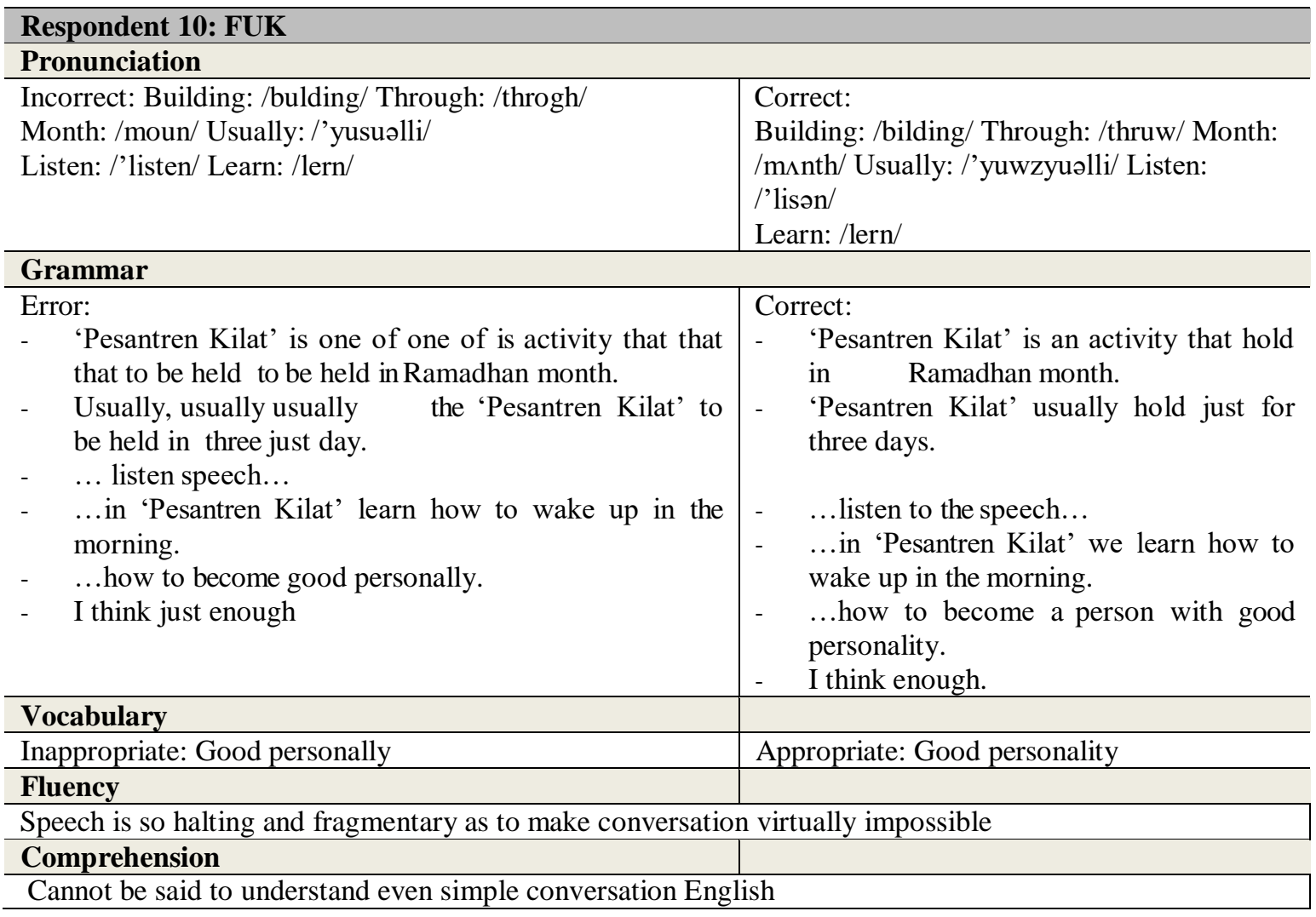

\section{CONCLUSIONS}

Based on the description in the previous chapter, it can be concluded that the students' speaking ability at University of Muhammadiyah Sorong was poor. The detail aspect of speaking occurred, Pronunciation was good, Grammar was fair, Vocabulary was fair, Fluency was poor, and Comprehension was poor which based on 30 respondents of fifth semester of English Department at University of Muhammadiyah Sorong.

\section{References}

Asmani, Jamal Ma'mur. 2011. Tips Pintar PTK: Penelitian Tindakan Kelas. Jakarta Selatan: Laksana.

Baker, J. \& Westrup H. 2003. Essential Speaking Skills: A Handbook for English Language Teachers. London: Continuum.

Bashir, M., et. al. 2011. Factor Effecting Students' English Speaking Skills. British Journal of Arts and Social Sciences, (online) Vol. II No.1. (http://www.bjournal.co.uk/BJASS.aspx., April 16, 2013).

Echols, John M and Hassan Shadily. 2006. An English-Indonesian Dictionary. Jakarta: PT. Gramedia Pustaka Utama.

Evans, Tony Dudley and Maggie Jo St John. 1998. Developments in English for Specific Purposes. United Kingdom: Cambridge University Press. 
Haris, David P. 1969. Testing English as a Second Language. New York: McGrawHill.

Harmer, Jeremy. 2007. How to Teach English.Shanghai: Longman Group.

Hue, Nguyen Minh. 2010. Encouraging Reluctant ESL/EFL Learners to Speak in the Classroom. The Internet TESL Journal, (online) Vol. XVI No.3. (http://iteslj.org., April 12, 2013).

Kayi, Hayriye. 2006. Teaching Speaking: Activities to Promote Speaking in a Second Language. The Internet TESL Journal, (online) Vol. XII No.11. (http://iteslj.org., April 12, 2013).

Palmer, Erik. 2011. Well Spoken: Teaching Speaking to All Students. New York: Stenhouse Publishers.

Richards, Jack C. \& Willy A. Renandya. Methodology in English Teaching. New York: Cambridge University.

Rowan, Paul. 2007. Building Speaking Skills by Creating 'Old-time Radio' Show. The Internet TESL Journal, (online) Vol. XIII No.1. (http://iteslj.org., April 12, 2013).

Shumin, Kang. 2002. Factors to Consider: Developing Adult EFL Students' Speaking Abilities. In Richards, Jack C. \& Willy A. Renandya. Methodology in English Teaching. New York: Cambridge University Press, pp. 205- 211.

Sudjana, Nana. 1989. Penilaian Hasil Proses Belajar Mengajar. Bandung: PT. Remaja Rosdakarya.

Tsang, W. K., \& Matilda Wong. 2002. Conversational English: An Interactive, Collaborative, and Reflective Approach. In Richards, J.C. \& Willy A. Renandya (eds.), Methodology in English Teaching. New York: Cambridge University Press, pp. 212-224.

Widiati, Utami \& Bambang Y. C. 2006. "The Teaching of EFL Speaking in the Indonesian Context: The State of the Art". Bahasa dan Seni, 